\title{
STRAWBERRY FRUIT RESISTANCE TO SIMULATED HANDLING
}

\author{
Marcos David Ferreira ${ }^{*}$; Steven Alonzo Sargent ${ }^{2}$; Jeffrey Karl Brecht² ${ }^{2}$ Craig Kellman \\ Chandler ${ }^{3}$ \\ ${ }_{2}^{1}$ Embrapa Instrumentação Agropecuária, C.P. 741 - 13560-970 - São Carlos, SP - Brasil. \\ ${ }_{3}^{2}$ University of Florida - Horticultural Sciences Department - 32611-0690 - Gainesville, FL - USA. \\ ${ }^{3}$ University of Florida - Gulf Coast Research \& Education Center - 33598 - Wimauma, FL - USA. \\ *Corresponding author <marcosferreira@ cnpdia.embrapa.br>
}

\begin{abstract}
Harvest operations are currently the main source of mechanical injury of strawberry (Fragaria x ananassa Duch.). Experiments were designed to simulate conditions encountered during commercial handling. Individual fruits were subjected to impact or compression forces with similar energy to determine the sensitivity to mechanical injury. Bruise volume was used as the measurement of injury. Bruise severity increased as a function of impact energy for both impact types. However, dropped fruits had larger bruise volume than fruits submitted to pendulum impactor at the same energy level. Doubling the impact energy $(0.040$ to $0.083 \mathrm{~J})$ increased bruise volume by 7 times $(13$ to $\left.91 \mathrm{~mm}^{3}\right)$. Fruits dropped from $380 \mathrm{~mm}(0.075 \mathrm{~J})$ showed $71 \%$ greater bruise volume than those dropped from either $130 \mathrm{~mm}(0.025 \mathrm{~J})$ or $200 \mathrm{~mm}(0.040 \mathrm{~J})$. Compressed fruits showed higher bruise volume than other tests. Some cultivars are more susceptible to compression forces than others. 'Sweet Charlie' berries showed bruise volume $40 \%$ higher than the others cultivars when subjected to compression. Fruits subjected to impact showed bruise volume lower than the compressed fruits, indicating the possibility to be handled and graded in a packing line.
\end{abstract}

Key words: Fragaria $x$ ananassa Duch., impact, compression, injury, grading

\section{RESISTÊNCIA FÍSICA DE MORANGOS SUBMETIDOS AO MANUSEIO}

RESUMO: A etapa de colheita é a principal fonte de danos físicos ao morango (Fragaria x ananassa Duch.). Experimentos foram realizados para simular condições encontradas durante manuseio. Frutos foram submetidos individualmente às forças de impacto e compressão em energias similares para determinar sensibilidade dos frutos a danos físicos. Volume da injúria física foi utilizado para mensurar a incidência do dano físico ocorrido. Severidade da lesão aumenta, com incremento da energia, tanto para força de impacto como para compressão. Todavia, frutos submetidos à queda livre demonstraram maiores volumes de danos físicos do que frutos submetidos a danos ocasionados por pendulo no mesmo nível de energia. Dobrando a energia de impacto $(0,040$ para $0,083 \mathrm{~J})$ ocorreu aumento no volume da injúria em sete vezes $\left(13\right.$ para $\left.91 \mathrm{~mm}^{3}\right)$. Frutos submetidos à queda de $380 \mathrm{~mm}(0,075 \mathrm{~J})$ demonstraram volumes de danos físicos $71 \%$ superiores do que aqueles ocasionados em queda de $130 \mathrm{~mm}(0,025 \mathrm{~J})$ ou $200 \mathrm{~mm}(0,040 \mathrm{~J})$. Frutos em teste de compressão mostraram maiores volumes de injúrias físicas do que outros testes. Alguns cultivares são mais sensíveis à força de compressão do que outros. Frutos cultivar 'Sweet Charlie' apresentaram volume de injúria $40 \%$ superiores do que outros quando submetidos à força de compressão. Morangos submetidos à força de impacto demonstraram volume de injúria inferior do que aqueles comprimidos, indicando a possibilidade dos morangos serem classificados e manuseados em uma linha de beneficiamento.

Palavras-chave: Fragaria x ananassa Duch., impacto, compressão, injúria, classificação

\section{INTRODUCTION}

Strawberry is a non-climacteric fruit, thus there is no respiratory and ethylene increase during ripening (Knee et al., 1977; Wills et al., 2004). The metabolic rate of strawberry is represented by the measured respiration rates (Kader, 2002). As non-climacteric fruit, it has to be harvested in an essentially ripe condition. Strawberries are hand harvested directly into the shipping flat (Albregts \& Howard, 1984; Rosemberg, 2004). Therefore, harvesting, grading and packing are done by the picker in the field. The advantage to this system is the reduction in the number of handling steps and manipulation. However, this harvesting system places more importance and responsibility on the pickers (Sherman, 1988). If the fruit is not picked to the right standards, the marketability of the crop may be impaired (Hochmuth, 1988). Alternatives to hand har- 
vest have been tried, mainly for berries destined to processing, but until now practically all strawberries for the fresh market are hand harvested. Harvesting is a very important step in the system in terms of quality and that losses can best be minimized at this step. After 8 days of storage at $5^{\circ} \mathrm{C}$ losses were about $33.7 \%$ for a less careful picker compared to $14.4 \%$ for a more trained picker (Mitchell et al., 1964).

Bruising can be caused by one or more types of contact: impact, compression, and vibration (Brusewitz et al., 1991; Vergano et al., 1991), and strawberries show more injury when subjected to compression (Holt \& Schoorl, 1976; Holt \& Schoorl, 1982). The physical evidence of bruising is a result of cell breakage. When subjected to a stress individual cells are distorted leading to cell wall extension and eventually breakage (Schoorl \& Holt, 1983). For strawberries, the amount of bruising is directly related to the energy absorbed (Holt \& Schoorl, 1982) due to their relatively large cell size and fragile nature of their cell walls (Szczesniak \& Smith, 1969).

Garcia et al. (1988) reported that in a packing line, fruits and vegetables are more likely to be subjected to impact forces and vibrational forces than compression force. It has been reported for several commodities, such as avocado, papaya, pineapple (Timm \& Brown, 1991), onion (Timm et al., 1991), tomato, bell pepper (Sargent et al., 1992), apple (Guyer et al., 1991; Sober et al., 1990) and citrus (Miller \& Wagner, 1991), that the number of transfers in a typical packing line associated with impact injury varies from six to ten. Injury can be caused by impact on hard surfaces, such as steel, especially when subjected to high drop heights (Sargent et al., 1992; Timm \& Brown, 1991).

The most common instrument used to study the effect of compression forces is the Instron Universal Testing Machine (Chen et al., 1987; Ballinger et al., 1973; Jamieson et al., 2002). Trials showed differences in the bruise volumes caused by impact and compression forces, depending upon the commodity (Guilou, 1964: Holt \& Schoorl, 1982). Holt \& Schoorl (1976) reported that apple tissue is more easily bruised by compression than by impact. Bruise volumes were approximately $40 \%$ higher under compression than impact.

For field packed strawberries, compression force has been reported to cause more severe bruising than impact force (Guilou, 1964). For the same amount of energy (0.2-1.5 J), bruise volumes in strawberries were $40 \%$ higher under compression compared to impact force (Holt \& Schoorl, 1982). It was proposed that this is due to the conformation of the cell wall: strawberry tissue is likened to an arrangement of liquid filled, spherical cells bounded by viscoelastic membranes with air filled interstitial spaces. Compression affects the cell wall, causing cell bursting, specially if under high stress.

Factors such as size, cultivar and ripeness stage can influence the response of fruit to compression pressure (Jamieson et al., 2002). Ourecky \& Bourne (1968) reported that small strawberry fruits subjected to compression pressure were firmer and tougher than medium and large fruits. The same results were reported for blueberry (Ballinger et al., 1973). Measurement of bioyield points yield information that is useful in comparing compression bruising susceptibility among different fruits. It has been reported that there is also some differentiation between firmness in strawberry cultivars, with some cultivars being firmer than others (Gooding, 1976; Holt \& Schoorl, 1982; Ourecky \& Bourne, 1968). The same results were reported for blueberries (Ballinger et al., 1973). Vergano et al. (1991) reported that green peaches subjected to compression pressure showed less injury than ripe fruits. Strawberry ripe fruits were reported to be softer than pink ones, being the difference reduced during storage (Doving \& Mage, 2002) and no difference in firmness was found between ripe and over-ripe fruit (Ourecky \& Bourne, 1968). On the other hand, Chen et al. (1987) reported that as Asian pears ripen they become less susceptible to compression bruising.

If strawberries could be picked and transported to a central facility for sorting and grading with minimal mechanical injury, different grades, custom packs, and potentially in-line cooling could be accomplished. The goal of this research was to evaluate the response of strawberry fruits to compression and impact simulating forces that can occur during removal of the berries from the plant during harvesting and also could happen on a packing line. Therefore it will be determined if exists a possibility that strawberry grading be done in a packing line.

\section{MATERIAL AND METHODS}

\section{Susceptibility of Strawberries to Impact and Com- pression Forces}

\section{Plant Material}

'Chandler', 'Oso Grande' and 'Sweet Charlie' strawberries were grown in the same condition in a commercial farm in Floral City, FL, USA (28 $4^{\prime}$ N, $82^{\circ} 0$ ' W). The berries were transported to a Postharvest Laboratory immediately after harvest and subjected to impact, drop or compression treatments. 'Chandler' 
was released in 1981, and show good fruit shape and taste quality. 'Oso Grande' fruits are large and have a conic to wedge shape. Excellent flavor, medium color to dark red. 'Sweet Charlie' shows a higher concentration of sugar and vitamin $\mathrm{C}$ and lower acidity than 'Oso Grande'. Early fruiting, productive and also produces fruits with excellent flavor (Chandler et al., 1997; Molinar \& Yang, 2001). All three cultivars were submitted to compression and impact tests, however, only 'Oso Grande' and 'Sweet Charlie' were used for the drop test. Strawberries selected for these tests were at the full ripe stage and were sorted for uniformity of size and freedom from visible damage. Berries were subjected to compression and impact tests at room temperature $\left(23\right.$ to $\left.24^{\circ} \mathrm{C}\right)$. All those cultivars were submitted to compression and impact tests. For drop tests only Oso Grande and Sweet Charlie were used.

\section{Impact Test}

Pendulum impactor - A pendulum impactor was used to apply preselected impact energies to the strawberry fruit. The berries were impacted by a chrome steel ball (32.61 g, diameter $20 \mathrm{~mm}$ ). An apparatus was constructed to permit controlled impacts on individual fruit. A pendulum (chrome steel ball bearing, 32.61 grams, diameter $=2 \mathrm{~cm}$ ) was attached by a swivel to monofilament line (88 Newtons test strength) and suspended from a fixed crossbar. A single berry was suspended in a cheesecloth pouch in contact with a solid backstop. The ball bearing was released from $60^{\circ}, 45^{\circ}$ and $25^{\circ}$, and permitted to impact the fruit once to simulate low- and high-impact energies of 0.040, 0.024, and $0.008 \mathrm{~J}$, respectively. The impact energy was calculated using the formula: $\mathrm{E}=\mathrm{mgh}$, where $\mathrm{m}=$ mass, $\mathrm{g}=$ acceleration due to gravity and $\mathrm{h}=\mathrm{r}-\mathrm{r} \cos \theta$ ( $\mathrm{r}=$ radius). There were $\mathrm{n}=30$ fruits per treatment.

Preliminary tests were done to determine those energy levels that caused external damage to strawberry, similar to those encountered under field conditions. Since the fruit swung freely, the pendulum impacted only once. 'Chandler' strawberries were tested once, while cultivars Sweet Charlie and Oso Grande were repeated twice. A total of 30 fruits were used in each treatment. In a second test, cultivar Oso Grande was also evaluated at three different angles of $90^{\circ}, 60^{\circ}$ and $45^{\circ}$ (energy of $0.083,0.040$, and $0.024 \mathrm{~J}$, respectively).

Drop tests - 'Oso Grande' and 'Sweet Charlie' strawberries of uniform size and weight ( $20 \mathrm{~g}$ ) were dropped from three heights 380, 200 and $130 \mathrm{~mm}$, measured from the middle of the fruit, onto a solid aluminum plate $(17 \mathrm{~kg})$. Considering an average strawberry weight of $20 \mathrm{~g}$, the equivalent impact energy levels were $0.075,0.040$, and $0.025 \mathrm{~J}$, for the three different heights, respectively. The fruit was attached to monofilament line with tape and held by the line before release in order to avoid rotational movement upon release of the berry. After impact, the fruit was caught by hand before impacting a second time. Blue chalk dust was scattered on the surface of the plate in order to mark the impact location on the fruit surface, which was then marked permanently to identify the impact site. 'Oso Grande' berries came from the field at $20^{\circ} \mathrm{C}$ and were allowed to reach room temperature $\left(24^{\circ} \mathrm{C}\right)$ prior to testing; 'Sweet Charlie' fruit were at $24^{\circ} \mathrm{C}$ when brought from the field. This test was conducted three times for 'Oso Grande', which was evaluated after one or two days of storage at $24^{\circ} \mathrm{C}$. One test was conducted for 'Sweet Charlie'evaluation was performed after one day of storage at $24^{\circ} \mathrm{C}$. A total of 20 fruits was used in each treatment and each fruit variety.

Compression tests were performed using the IFAS Firmness Tester developed at the Horticultural Sciences Department, University of Florida (Gull, 1987). A static load of $9.8 \mathrm{~N}$ was applied to the fullest point on one side of each strawberry fruit using a convex tip probe $15 \mathrm{~mm}$ in diameter. During preliminary tests, 'Oso Grande' strawberries were subjected to compression for 2 or $5 \mathrm{~s}$ using the IFAS Firmness Tester. Bruise volume after $5 \mathrm{~s}$ compression $\left(301 \mathrm{~mm}^{3}\right)$ was $53 \%$ greater than for $2 \mathrm{~s}$ compression $\left(197 \mathrm{~mm}^{3}\right)$ and the fruit skin tended to be sheared by the edge of the probe. Therefore, due to this excessive injury, subsequent tests with 'Chandler' and 'Sweet Charlie' utilized a compression time of $2 \mathrm{~s}$. A total of 30 fruits was used in each treatment.

Considerable effort was made in the design of these experiments to simulate impact and compression bruises such as are encountered during commercial strawberry handling. The use of the same cultivars, ripeness stage, pulp temperature, time after harvest and number of replicates were carefully controlled to minimize variability. The impact energy values for the pendulum tests and those from fruit drop tests were similar, while the compression tests were designed to rapidly induce uniform compression bruises.

\section{Bruise Evaluation}

Strawberries were stored at $24^{\circ} \mathrm{C}$ and 90 to $95 \%$ of RH for 24 to 48 hours after treatment. The berries were cut through the center of the impact area and the diameter and depth of the bruised tissue was measured using a caliper $(+-0.1 \mathrm{~mm})$. Bruise width (w) was measured from edge to edge of the bruise on two perpendicular axes and averaged. Bruise depth 
(D) was measured from the fruit surface to the deepest point of the damaged tissue. Total bruise volume (V) was calculated assuming a cone shape, using $\mathrm{V}=1 /$ $3\left(\pi[\mathrm{w} / 2]^{2} \mathrm{D}\right)$ (Mohsenin, 1970). Bruise incidence was based on whether a bruise was visible at the cut surface of the fruit below the impacted area.

\section{Statistical Analyses}

A completely randomized design was used for experiments. Analyses of variance were performed using the Statistical Analysis Systems computer package (SAS Institute, 1986). Unless cultivars revealed significant differences, overall treatment means were compared by Least Significant Differences $(p=0.05)$. Otherwise, means from each cultivar were analyzed separately.

\section{RESULTS AND DISCUSSION}

\section{Susceptibility of Strawberries to Impact and Com- pression Forces}

Pendulum impact tests - The individual cultivars, 'Chandler', 'Sweet Charlie' and 'Oso Grande', did not show differences in bruise volume $(p=0.8392)$ after being injured by three pendulum impactor energy levels $0.008,0.024$ and $0.040 \mathrm{~J}$ (data not shown). However, when cultivar averages were combined, the overall bruise volume was continuously increased with the impact energy increase $(p=0.05)$ for impacts energy from 0.008 to $0.040 \mathrm{~J}$ (Table 1). The main reason for this combining was due to the heterogeneity of fruit response to physical damage. By increasing impact energy from 0.040 to $0.083 \mathrm{~J}$ 'Oso Grande' strawberries bruise volume increased seven times resulting in a mean value increase from 13 to $91 \mathrm{~mm}^{3}$ (Table 2 ), however there was no difference in bruise volumes of strawberries impacted at either lower energy impact, 0.024 and $0.040 \mathrm{~J}$. The impact tests determined the relative sensitivity of three major strawberry cultivars at $24^{\circ} \mathrm{C}$ pulp temperature to bruises that could

Table 1 - Combined bruise volumes for 'Chandler', 'Oso Grande' and 'Sweet Charlie' strawberry varieties subjected to three pendulum impact angles. $\mathrm{n}=30$ fruits.

\begin{tabular}{lcc}
\hline Angle & Impact Energy & Bruise Volume \\
\hline & $\mathrm{J}$ & $\mathrm{mm}^{3}$ \\
$25^{\circ}$ & 0.008 & $7 \mathrm{a}^{*}$ \\
$45^{\circ}$ & 0.024 & $34 \mathrm{~b}$ \\
$60^{\circ}$ & 0.040 & $51 \mathrm{c}$ \\
\hline$L S D$ at $p 0.05$ & & 16 \\
\hline
\end{tabular}

*Means followed by the same letter in the column are not different by LSD test $(p<0.05)$. occur during harvest or handling on a packing line. During handling, strawberry can be subject to different impact, therefore high impact level may be avoid during processing.

Drop tests - Combined average bruise volumes of 'Oso Grande' and 'Sweet Charlie' strawberries showed that those dropped from $380 \mathrm{~mm}(0.075 \mathrm{~J})$ had $71 \%$ greater bruise volume than those dropped from either $130 \mathrm{~mm}(0.025 \mathrm{~J})$ or $200 \mathrm{~mm}(0.040 \mathrm{~J})$ (Table 3). Bruise severity increased as impact energy increased for both the pendulum (Table 1) and drop (Table 3) tests. Bruise volume in strawberry is directly related to the energy absorbed (Holt \& Schoorl, 1982), while the high bruise susceptibility of strawberries is apparently due to the large cell size and the fragile nature of the cell walls (Szczesniak \& Smith, 1969). Therefore, avoiding transfer points, especially with elevate hights is a crucial point on designing a strawberry packing line. Carefull handling, especially when picking and dropping on boxes, also will contribute for physical injury incidence.

Compression Tests - Bruise volume for 'Sweet Charlie' berries was significantly higher (40\%) than 'Oso Grande'; however was not significantly different from 'Chandler' (Table 4). Injuries caused by impact and compression may be related to the conformation of the cell wall. Impacts cause failure of the

Table 2 - Bruise volumes for 'Oso Grande' strawberry varieties subjected to three pendulum impact angles. $\mathrm{n}=30$ fruits.

\begin{tabular}{lcc}
\hline Angle & Impact Energy & Bruise Volume \\
\hline & $\mathrm{J}$ & $\mathrm{mm}^{3}$ \\
$45^{\circ}$ & 0.024 & $12 \mathrm{a}$ \\
$60^{\circ}$ & 0.040 & $13 \mathrm{a}$ \\
$90^{\circ}$ & 0.083 & $91 \mathrm{~b}$ \\
\hline$L S D$ at $p 0.05$ & & 27
\end{tabular}

*Means followed by the same letter in the column are not different by LSD test $(p<0.05)$.

Table 3 - Combined bruise volumes for 'Oso Grande' and 'Sweet Charlie' strawberry varieties subjected to three drop heights. $\mathrm{n}=20$ fruits.

\begin{tabular}{|c|c|c|}
\hline Angle & Impact Energy & Bruise Volume \\
\hline $\mathrm{mm}$ & $\mathrm{J}$ & $\mathrm{mm}^{3}$ \\
\hline 130 & 0.025 & $152 \mathrm{a}$ \\
\hline 200 & 0.040 & $120 \mathrm{a}$ \\
\hline 380 & 0.075 & $233 \mathrm{~b}$ \\
\hline LSD at $p 0.05$ & & 52 \\
\hline
\end{tabular}

*Means followed by the same letter in the column are not different by LSD test $(p<0.05)$. 
Table 4 - Bruise volumes for 'Chandler', 'Oso Grande' and 'Sweet Charlie' strawberry varieties after compression test ${ }^{2}$.

\begin{tabular}{lc}
\hline Cultivar & Bruise Volume \\
\hline $\mathrm{mm}$ & $\mathrm{mm}^{3}$ \\
Chandler & $460 \mathrm{a}$ \\
Oso Grande & $498 \mathrm{a}$ \\
Sweet Charlie & $644 \mathrm{~b}$ \\
\hline$L S D$ at $p 0.05$ & 134 \\
\hline
\end{tabular}

z9.8 $\mathrm{N}$ for $2 . \mathrm{n}=30$ fruits. *Means followed by the same letter in the column are not different by LSD test $(p<0.05)$.

intercellular bonds or actual cleavage of the cells, whereas compression under constant load affects the viscoelastic cell wall, causing cell bursting under high stress. This statement confirms the results found where fruits subjected to impact showed less bruise volume. Compression bruising occurs normal to the direction of the force, commonly appearing as a line of cells whose walls have buckled and fractured which allows the cell contents to escape (Vincent, 1990). Under a static load, the sinuous microfibrils straighten out and then slip relative to each other. On the other hand, an impact causes the microfibrils to straighten out and snap (Holt \& Schoorl, 1976; Holt \& Schoorl, 1982). Therefore, since more energy is dissipated in the breaking of microfibrils during an impact stress, resultant bruise severity is less than it under a compressive load (Holt \& Schoorl, 1976).

\section{CONCLUSION}

Strawberry bruising starts in the field and is more likely induced by compression stress during harvest, field pack and subsequent handling operations. Strawberries are also susceptible to bruising due to impact stress as would be encountered during handling on a commercial packing line. However, if impact could be reduced below the thresholds found in this study, it would be possible to grade strawberrries on a packing line, providing the potential to pack with more consistent grade standards.

\section{REFERENCES}

ALBREGTS, E.E.; HOWARD, C.M. Strawberry production in Florida. Gainesville: Florida Cooperative Extension ServiceUniversity of Florida , 1984. 26p.

BALLINGER, W.E.; KUSHMAN, L.J.; HAMANN, D.D. Factors affecting the firmness of highbush blueberries. Journal of the American Society of Horticultural Science, v.98, p.583587, 1973.

BRUSEWITZ, G.H.; MCCOLLUM, T.G.; ZHANG, X. Impact bruise resistance of peaches. Transactions of the ASAE, v.34, p.962965,1991
CHANDLER, C.K.; ALBREGTS, E.E.; HOWARD, C.M.; BRECHT, J.K. 'Sweet Charlie' Strawberry. HortScience, v.32, p.11321133,1997

CHEN, P.; RUIZ, M.; LU, F.; KADER, A. Study of impact and compression damage on Asian pears. Transactions of the ASAE, v.30, p.1193-1197, 1987.

DOVING, A.; MAGE, F. Methods ot testing strawberry fruit firmness. Acta Horticultura Scandinava, v.52, p.43-45, 2002.

GARCIA, C.; RUIZ, M.; CHEN, P. Impact parameters related to bruising in selected fruits. St. Joseph: ASAE, 1988. 16p. (American Society of Agricultural Engineers Meeting, 886027).

GOODING, H..J. Resistance to mechanical injury and assessment of shelf life in fruits of strawberry (Fragaria ananassa). Horticulture Research, v.16, p.71-82, 1976.

JAMIESON, A.R; FORNEY, C.F.; RICHARDS, K.U.K.G; HIETARANTA, T.; LINNA, M.M.; PALONEN, P.; PARIKKA, P. Strawberry fruit characteristics that contribute to postharvest postharvest quality. Acta Horticulturae, v.567, p.723-726, 2002.

GUILOU, R. Orderly development of produce containers. In: FRUIT AND VEGETABLE PERISHABLES HANDLING CONFERENCE, Davis, 1964. Proceedings. Davis: University of California, 1964. p.23-25.

GULL, D.D. A simplified firmness tester for horticultural products. HortScience, v.22, p.1146, 1987.

GUYER, D.E.; SCHULTE, N.L.; TIMM, E.J.; BROWN, G.K. Minimizing apple bruising in the packingline. Tree Fruit Postharvest Journal, v.2, p.14-20, 1991.

HOCHMUTH, G.J. Strawberry production guide for Florida. Gainesville: Florida Cooperative Extension Service-University of Florida, 1988. 17p. (Circular 142C).

HOLT, J.E.; SCHOORL, D. Bruising and energy dissipation in apples. Journal of Textures Studies, v.7, p.421-432, 1976.

HOLT, J.E.; SCHOORL, D. Strawberry bruising and energy dissipation. Journal of Textures Studies, v.13, p.349-357, 1982.

KADER, A.A. Postharvest biology and technology: an overview. In: KADER, A.A. (Ed.) Postharvest technology of horticultural crops. Davis: University of California, 2002. p.39-47. (Publication 3311).

KNEE, M.; SARGENT, J.A.; OSBORNE, D.P. Cell wall metabolism in developing strawberry fruits. Journal of Experimental Botany, v.28, p.377-396, 1977.

MILLER, W.M.; WAGNER, C. Florida citrus packing line studies with an instrumented sphere. Applied Engineering in Agriculture, v.7, p.577-581, 1991.

MITCHELL, F.G.; MAXIE, E.C.; GREATHE, A.S. Handling strawberries for fresh market. Davis: University of California, 1964. 16p.

MOHSENIN, N.N. Physical properties of plant and animal materials. New York: Gordon and Breach Science, 1970. $742 p$.

MOLINAR, R.; YANG, M. Strawberry variety trial. Fresno: UC Cooperative Extension, 2001. 2p.

OURECKY, D.K.; BOURNE, M. C. Measurement of strawberry texture with an Instron machine. Proceedings of the American Society for Horticultural Science, v.93, p.317 325,1968

ROSEMBERG, H.R. Many fewer steps for pickers: a leap for harvestkind? Emerging change in strawberry harvest technology. Choices Magazine, 2004. Available at: http:// www.choicesmagazine.org/2004-1/2004-1-02.htm. Accessed 9 Nov. 2006.

SARGENT, S.A.; BRECHT, J. K.; ZOELLNER, J.J. Instrumented sphere impact analyses of tomato and bell pepper packing lines. Applied Engineering in Agriculture, v.8, p.76-83, 1992.

SAS INSTITUTE. Statistical analysis systems computer package. Cary: SAS Institute, 1986. 
SCHOORL, D.; HOLT, J.E. Mechanical damage in agricultural products: a basis for management. Agricultural Systems, v.11, p.143-157, 1983.

SHERMAN, M. Harvesting and handling. In: HOCHMUTH, G. J. (Ed.) Strawberry production guide for Florida. Gainesville: Florida Cooperative Extension Service-University of Florida, 1988. p.14-17. (Circular, 142C).

SOBER, S.S.; ZAPP, H.R.; BROWN, G.K. Simulated packing line impacts for apple bruise prediction. Transactions of the ASAE, v.33, p.629-636, 1990.

SZCZESNIAK, A.S.; SMITH, B.J. Observations on strawberry texture a three-pronged approach. Journal of Textures Studies, v.1, p.65-89, 1969.

TIMM, E.J.; BROWN, G.K. Impacts recorded on avocado, papaya, and pineapple packing lines. Applied Engineering in Agriculture, v.7, p.418-422, 1991.
TIMM, E.J.; BROWN, G.C.; BROOK, R.C.; SCHULTE, N.L.; BURTON, C.L. Impact bruise estimates for onion packing lines. Applied Engineering in Agriculture, v.7, p.571-576, 1991. VERGANO, P.J.; TESTIN, R.F.; NEWALL, W.C. Peach bruising: susceptibility to impact, vibration, and compression. Transactions of the ASAE, v.34, p. 2110-2116, 1991.

VINCENT, J.F.V. Fracture properties of plants. In: CALLOW, J.A. (Ed.) Advances in botanical research. London: Academic Press, 1990. cap.17, p.235-287.

WILLS, R.B.H.; McGLASSON, W.B.; GRAHAM, D.; JOYCE, D. Postharvest: an introduction to the physiology \& handling of fruit, vegetables \& ornamentals. 4 ed. Wallingford: CABI, 2004. $262 \mathrm{p}$.

Received February 12, 2007

Accepted April 11, 2008 